\title{
REKONSTRUKSI MAKNA MURTAD DAN IMPLIKASI HUKUMNYA
}

\author{
Abdur Rahman ibn Smith \\ Bagian Fatwa Masjid BesarKauman Semarang \\ e-mail: rajapublishing@yahoo.com
}

\begin{abstract}
Riddah interpreted by fuqahä' as those who leave Islam. The punishment was killed based on hadith "man baddala dinahu faqtulūh." That understanding is different from the description of the Qur'an in the related verses that actually gives punishment neither physical, but non-physical. Those verses are: al-Hajj: 11, al-Mā'idah: 54, al-Naḥl: 106, alNisā': 137, Āli 'Imrān: 86, and al-Baqarah: 217. Study of the verses of the Qur'an shows that none of the text with șärih-lafaiyyah approach that lead to aggressive and emotional attitude to the suspect of riddah. On the other hand the Qur'an asserted that the type of the punishment is eschatological and negates physical punishments. This qualitative research will intends to make reconstruction of riddah meaning and its legal implications. With a historical approach, juridical, philosophical, ideological and comparative of the riddah meaning contained in the Koran, hadith, and socio-historical perspective, then the reconstruction of the meaning of riddah should be understood to be more humane, comprehensive, and in accordance with maqāsid sharīah.
\end{abstract}

[]

Riddah dimaknai oleh ulama fikih sebagai orang yang keluar dari Islam. Hukumannnya adalah dibunuh berdasarkan hadis "man baddala dīnahu faqtulūh." Pemahaman tersebut berbeda dengan gambaran al-Qur'an dalam ayat-ayat terkait yang justru memberikan hukuman yang tidak satu pun bersifat fisik, melainkan non fisik. Ayat-ayat al-Qur'an tersebut adalah: al-Hajj: 11, al-Māidah: 54, al-Nahl: 106, al-Nisā': 137, Āli 'Imrān: 86, dan al-Baqarah: 217. Telaah atas ayat-ayat al-Qur'an tersebut menunjukkan bahwa tidak satu pun teks secara șārihh-lafżiyyah yang mengarah kepada sikap agresif dan emosional terhadap pelaku riddah. Sebaliknya, al-Qur'an menegaskan sanksinya bersifat eskatalogis; dan menegasikan sanksi fisik. Penelitian kualitatif ini menawarkan upaya rekonstruksi makna riddah dan implikasi hukumnya. Dengan pendekatan historis, yuridis filosofis, ideologis dan komparatif terhadap makna yang terdapat dalam al-Qur'an, hadis, dan sosio-historis yang terkait dengan riddah, rekonstruksi terhadap makna riddah semestinya menjadi lebih humanis, komprehensif dan sesuai maqasid syari'ahnya.

Keywords: riddah,jināyah, implikasi hukum, sanksi hukum

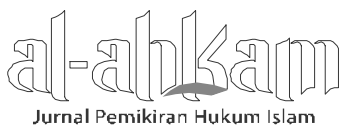




\section{Pendahuluan}

Murtad dalam wacana fikih difahami sebagai orang yang keluar dari Islam dan berpindah memeluk agama lain. Jika seseorang yang murtad tetap berpaling setelah diminta bertobat, maka hukumnya adalah dibunuh. ${ }^{1}$ Pendapat tersebut salah satunya didasarkan pada hadis "man baddala dinahu faqtulūh".2 Dengan demikian menurut hukum pidana Islam tindakan murtad (apostasy) termasuk kategori ḥudūd. ${ }^{3}$

Hal tersebut berbeda dengan penjelasan dalam al-Qur'an, bahwa hukuman atas murtad adalah di antaranya: amalan menjadi sia-sia di dunia dan di akhirat dan dimasukkan dan kekal di dalam neraka, ${ }^{4}$ dimurkai Allah, ${ }^{5}$ dilaknat Allah, para malaikat dan semua manusia. ${ }^{6}$ Penjelasan al-Qur'an tersebut selaras dengan larangan memaksakan agama terhadap orang lain sebagaimana kasus Ḥusayn dari Banī Salīm ibn 'Awf dari golongan Anshar yang datang menghadap Nabi meminta izin untuk memaksa kedua anaknya yang masih beragama Nasrani untuk menjadi seorang Muslim, sehingga turunlah ayat 256 surat al-Baqarah sebagai teguran. ${ }^{7}$

Menurut Abdullah Yusuf Ali, tindakan pemaksaan kepada Islam dalam bentuk apapun, bertentangan dengan al-Qur'an.8 ${ }^{8}$ Pendapat tersebut selaras dengan pen-

\footnotetext{
1Lihat 'Abd al-Qādir 'Awdah, al-Tashrī' al-Jinā'î al-Islāmī, Muqāranan bi al-Qānūn al-Waḍ'ì, Jilid I (Beirut: Dār al-Kitāb al-Bābī, t. th.),h. 78.

2Muhammad ibn Ismāīl al-Bukhārī, Șahịh al-Bukhārī (Beirut: Dār al-Fikr, 1401 H/1981), Jilid VIII, h. 50; Matn al-Bukhārī bi Hāshiyyah al-Sindī, Jilid IV (Beirut: Dār al-Fikr, 1995), h. 316.

${ }^{3}$ Ada tiga kategori saksi hukum dalam pidana Islam, yaitu: hudud, qishash-diyat, dan ta'zir. Tindakan pidana yang kuantitas dan kualitas telah ditentukan hukumnya oleh naș, dinamakan hudud. Tindakan pidana tersebut meliputi pencurian (sariqah), perampokan (hirabah), zina, menuduh berzina (qadhaf), mabuk (sukr), dan pemberontakan terhadap negara Islam (bughah). Sedangkan qișāss-diyat adalah tindakan pidana pembunuhan dan melukai anggota badan serta dikenai hukum baik dengan qishash (balasan setimpal) ataupun diyat (denda dengan uang atau yang senilai dengannya) bagi korban atau sanak familinya. Sementara ta'zir, adalah ketentuan hukum atas tindak pidana yang tidak termasuk hudud dan qishash-diyat, karenanya ketentuan legalnya diserahkan kepada kebijakan penguasa. Lihat Abdul Qadir al-'Audah, al-Tashrī' al-Jinā'ily al-Islāmīi, h. 78-79.
}

${ }^{4} \mathrm{QS}$. al-Baqarah: 218.

5QS. al-Māidah: 54.

6QS. Āli 'Imrān: 86-91.

${ }^{7}$ QS. Al-Baqarah: 256. Artinya: "Tidak ada paksaan dalam beragama [Islam]. Sungguh kebenaran telah nyata dari kesesatan". Baca: Muhammad Rashīd Riḍā, Tafsìr al-Manār, Jilid III (Beirut: Dār alFikr, t.th.), h. 36; Muhammad Ḥasan al-Hamashī, Qur'an Karim: Tafsìr wa Bayān (Damaskus: Dār alRushd, t.th.), h. 83.

${ }^{8}$ Abdullah Yusuf Ali, The Glorious Kur'an, Translation and Commentary (Beirut: Dār al-Fikr, t. th.), h. 103. 
dapat Aisyah Abdurrahman bintu al-Syāthi' yang menjelaskan bahwa larangan pemaksaan beragama itu adalah untuk memastikan bahwa akidah itu benar-benar bersumber dari keyakinan hati, karena tidak ada iman yang benar kecuali bila berasal dari hati yang tulus, murni, tenang dan jujur. Pemaksaan hanya akan menghasilkan pengakuan di mulut, tetapi pengingkaran di dalam hati, dan itu adalah kemunafikan yang oleh Islam dianggap sebagai kekafiran yang paling jahat. ${ }^{9}$

Hal yang sama dijelaskan Muhammad Quraish Shihab, bahwa kebebasan beragama merupakan bagian dari hak kebebasan berpendapat. Karena hal itu adalah hak yang dianugerahkan Tuhan bagi setiap insan. Al-Qur'an juga mengakui kenyataan tentang banyaknya jalan yang dapat ditempuh umat manusia. Jalan yang banyak itu dalam terminologi al-Qur'an disebut subūl al-salām. ${ }^{10}$ Pada jalan yang banyak itu, manusia diperintahkan untuk berlomba-lomba dalam kebajikan (fastabiqu al-khayrāt), ${ }^{11}$ semuanya demi kedamaian dan kerukunan. ${ }^{12}$

Beberapa ilmuwan-pun menjelaskan hal yang sama seperti Djohan Effendi, 13 Nurcholis Madjid,14 Said Aqil Husin al-Munawwar,"15 Sayid Jawad Mushthafawi, sebagaimana dikutip Fahmi Huwaydi, ${ }^{16}$ mereka berpendapat bahwa pemaksaan agama bukanlah ajaran yang dibetulkan menurut agama. Bahkan ketika kasus ulama alAzhar Mesir mengkafirkan dan menganggap murtad terhadap Nașr Ḥāmid Abū Zayd, Qāsim Amīn (1898), 'Alī 'Abd. al-Rāziq (1925), Țāha Ḥusayn (1926), Najib Mahfūz (1956), dan Farag Fauda (1992), makna murtad tidak lagi bermakna konversi kepada agama selain Islam, tetapi juga berarti pemikiran yang keluar dari "jalur resmi".

Artikel ini merupakan hasil penelitian yang akan merekonstruksi konsep murtad dalam perspektif fikih jināyat serta akibat hukum dari pemahaman murtad

\footnotetext{
9'Aisyah Abdurrahman bintu al-Syāthi', Manusia: Sensitivitas Hermeneutik al-Quran, terj. M. Adib al-Arief (Yogyakarta: LKPSM, 1997), h. 95-96.

${ }^{10}$ QS. al-Māidah: 16.

11QS. al-Baqarah: 148.

12M. Quraish Shihab, Wawasan al-Quran (Bandung: Mizan, 1996), h. 365.

${ }_{13}$ Djohan Effendi, "Harus Ada Kebebasan Tidak Beragama", dalam Wajah Liberal Islam di Indonesia, [Editor], Luthfi Asy-Syaukani (Jakarta: Jaringan Islam Liberal, 2002), h. 135.

${ }^{14}$ Nurcholis Madjid, Islam Kemodernan dan Keindonesiaan (Bandung: Mizan, 1989), h. 56. 49-50.

${ }^{15}$ Said Aqil Husin al-Munawwar, Fikih Hubungan Antar Agama (Jakarta: Ciputat Press, 2005), h.

16Fahmi Humaydi, Demokrasi Oposisi dan Masyarakat Madani, terj. Muhammad Abdul Goffar E.M. (Bandung: Mizan, 1996), h. 168.
} 
dalam perspektif fikih jināyat yang inklusif dengan pendekatan historis, yuridis filosofis dan ideologis. ${ }^{17}$ Kajian ini secara metodologis akan mendekonstruksi dengan melakukan pembacaan kritis terhadap teks keagamaan yang ahistoris, diskriminatif dan sektarian, sehingga selanjutnya upaya rekonstruksi dilakukan agar makna riddah dipahami lebih humanistik dan pluralistik. Disamping itu, dalam membaca teks dilakukan secara instrinsik dan ekstrinsik. Pembacaan teks secara intrinsic untuk mengetahui latar belakang penulis dan historis. ${ }^{18}$ Sedangkan secara ekstrinsik menawarkan satu cara pandang alternatif dalam pembacaan atas pemikiran ulama hukum dalam melakukan dekonstruksi. Pendekatan tematik (maw dụ'í) dilakukan dengan cara menghimpun ayat-ayat al-Qur'an yang mempunyai maksud yang sama dalam membicarakan satu tema/topik tertentu dan menyusunnya berdasarkan kronologis serta sebab turunnya ayat, kemudian memberi keterangan dan penjelasan serta mengambil kesimpulan. ${ }^{19}$

\section{Makna Murtad dan Implikasi Hukumnya}

Secara morfologi, terma murtad adalah bentuk subjek (ism al-fă'il) dari kata kerja irtadda. Secara etimologis kata irtadda berasal dari kata kerja "radda, yaruddu, riddah, yang berarti "șarafahu", yaitu mengalihkan dan "arja'ahu" yaitu mengembalikan. Pengertian itu digunakan dalam bentuk-bentuk kembali ke rumah, manfaat yang diperoleh dari perbuatan, atau mengembalikan jawaban dan atau menerima pernyataan orang. ${ }^{20}$ Riddah itu dapat pula diartikan kembali dijalan asalnya, yaitu kembalinya seorang Muslim yang akil baligh, dari agama Islam kepada bentuk kafir tanpa ada paksaan dari manapun. ${ }^{21}$

Riddah juga berarti berarti mundur atau kembali ke belakang.22 Sayyid Sabiq dalam Fiqh al-Sunnah, mengartikan riddah dengan al-rujü' 'an al-țaīq alladhī jā'a

\footnotetext{
17Muhammad 'Abed al-Jābirī, Naḥnu wa T-Turāth: Qirāat Mu'așirah fi Turathinā al-Falsafi (Beirut: Al-Markaz al-Thaqafi al-'Arabī), h. 24.

${ }^{18}$ Noeng Muhadjir, Metodologi Penelitian Kualitatif (Yogyakarta: Rake Sarasin, 1996), h. 164-165.

${ }^{19}$ Abdul Hayy al-Farmawy, Metode Tafsir Maudhu'i, Terj. Suryan A. Jamrah Oakarta: Rajawali Press, 1994), h. 34. h. 218.

${ }^{20}$ Ibn Manzūr al-Anșāri, Lisān al-'Arab, Vol II (Mesir: al-Dār al-Miṣriyyāt li 1-Ta'lïf wa al-Nashr, t.th. ),

21al-Sayyid Sābiq, Fiqh al-Sunnah, Jilid II (Beirut: Dār al-Fikr, 1983), h. 381.

${ }^{22}$ Ahmad Warson Munawwir, Kamus Al-Munawwir (Yogyakarta: Yayasan Pondok Pesantren Krapyak, 1995), h. 522.
} 
minhu yaitu kembali atau mundur dari jalan di mana ia datang.23 Sementara Wahbah al-Zuhaylī dalam al-Fiqh al-Islāmī wa Adillatuh, mengartikannya dengan kembali dari sesuatu kepada yang lainnya (al-rujü' 'an al-shay' ilā ghayri). ${ }^{24}$ Dalam terminologi fikih, Wahbah al-Zuhaylī memaknai riddah dengan "Keluar dari agama Islam menjadi kafir, baik dengan niat, perkataan maupun perbuatan yang menyebabkan orang yang bersangkutan dikategorikan kufur/kafir".25 Sementara Sayyid Sābiq dalam Fiqh al-Sunnah mendefinisikan riddah dengan: "Keluarnya seorang Muslim yang telah dewasa dan berakal sehat dari agama Islam kepada kekafiran, baik dengan niat, dengan kehendaknya sendiri tanpa paksaan dari siapa pun ".26

Secara redaksional kedua rumusan di atas berbeda. Tetapi secara subtansial adalah sejalan. Kedua rumusan di atas menegaskan bahwa ada tiga unsur riddah, yaitu: pertama, pelakunya adalah orang sehat dan dewasa; kedua, riddah dilakukan atas kesadaran sendiri; dan bukan atas paksaan; dan ketiga, riddah dilakukan baik dengan hati, perkataan dan perbuatan.

Pandangan di atas sejalan dengan kategori Abd al-Qādir 'Awdah bahwa riddah bermakna keluar dari agama Islam dan tidak menerima sebagian ajaran-Nya serta menentang sebagian yang diwajibkan-Nya. ${ }^{27}$ Pendapat tersebut searah dengan pendapat Noerwahidah bahwa murtad itu merupakan suatu pernyataan sikap yang disusul dengan tindakan keluar dari Islam, pelakunya sebelum itu adalah penganut agama Islam. ${ }^{28}$

Dari pengertian terminologi di atas dapat disimpulkan bahwa murtad adalah keluar dari Islam. Kategori ini dinamakan murtad teologis. Sedangkan riddah yang dinyatakan secara verbal, maupun non verbal berupa pernyataan sikap dan pengingkaran hati tanpa disertai dengan sikap pindah ke agama lain disebut riddah fi'li dan qawli. Bahkan menurut Muhammad Abduh murtad adalah keluarnya seseorang dari tiga dasar yang sangat fundamental yaitu: keluar dari keyakinan

\footnotetext{
${ }^{23}$ al-Sayyid Sābiq, Fiqh al-Sunnah....., h. 450.

${ }^{24}$ Wahbah al-Zuhaylī, al-Fiqh al-Islāmiy wa Adillatuh, Juz VII (Damaskus: Dār al-Fikr al-Mu'āṣir, t. th.), h. 183.

${ }^{25}$ Wahbah al-Zuhaylī, al-Fiqh al-Islāmī...., h. 183

26al-Sayyid Sābiq, Fiqh al-Sunnah....., h. 451.

${ }^{27} \mathrm{Abd}$. al-Qādir 'Awdah, al-Tashrī' al-Jināî al-Islāmi Muqarinan bi al-Qānūn al-Waḍ'ī, Juz II (t.t.p.: Muassasah al-Risālah, t.th.), h. 707. 65.

${ }^{28}$ Noerwahidah AH, Pidana Mati dalam Hukum Pidana Islam (Surabaya: al-Ikhlas, 1994), Cet I, h.
}

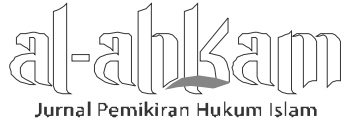

Volume 22, Nomor 2, Oktober 2012 
bahwa alam ini diatur oleh satu Tuhan; keluar dari keimanan kepada alam ghaib dan kehidupan dunia akhirat; serta keluar dari amal saleh yang bermanfaat bagi diri manusia dan masyarakat. ${ }^{29}$ Kategori riddah pertama bersifat teologis (rubūbiyah); yang kedua eskatologis; dan terakhir bersifat destruktif.30

\section{Riddah dalam Pandangan Hukum Pidana Islam}

Dalam diskursus pidana Islam, tindakan riddah dikategorikan sebagai jarīmah ḩudūd, yaitu suatu tindak kejahatan yang sanksi hukumnya didasarkan atas naș, atau penetapan hukumnya tidak didasarkan atas kebijakan pemerintah. Pemberian sanksi atas pelaku riddah dimaksudkan seseorang tidak mudah melakukan perbuatan jarimah dan demi terwujud kemaslahatan umat. Kemaslahatan dimaksud adalah perlindungan terhadap agama, jiwa, keturunan, akal dan harta benda. ${ }^{31}$ Dengan kata lain, pemberian sanksi atas pelaku riddah sebagai realisasi atas hifz al-dīn (perlindungan terhadap agama).

Pemberian sanksi dapat dilakukan manakala terpenuhinya syarat dan rukun. Adapun rukun riddah dapat dibedakan rukun umum dan khusus. Yang dimaksud rukun umum adalah unsur-unsur yang harus terpenuhi pada setiap jarimah. ${ }^{32}$ Unsur-unsur tersebut terdiri atas unsur formil, materil dan moril. Unsur pertama (unsur formil) adalah undang-undang atau nas. Artinya perbuatan tidak dianggap melawan hukum dan pelakunya tidak dapat dikenai sanksi pidana, kecuali adanya nas atau undang-undang yang mengaturnya atau disebut asas legalitas dalam hukum positif. ${ }^{33}$ Dalam hukum Islam diistilahkan dengan al-rukn al-shar'î. Menurut 'Abd al-Qādir 'Awdah, kaidah yang mendukung unsur ini adalah "Tidak ada perbuatan yang dianggap melanggar hukum dan tidak ada hukuman yang dijatuhkan kecuali adanya ketentuan naș"34 318.

${ }^{29}$ Muḥammad 'Abduh, Tafsìr al-Manār, Juz II (Beirut: Dār al-Ma'ārif li I-Ṭibā'ah wa I-Nashr), h.

30Pendapat yang sama diungkapkan A. Jazuli, Fiqh Jinayah Upaya Menanggulangi Kejahatan dalam Islam, Cet. I (Jakarta: Raja Grafindo Persada, 1996), h. 114.

31'Abd al-Wahhāb Khallāf, Ilmu Ushul......,h. 198.

32Makhrus Munajat, Dekonstruksi Hukum Pidana Islam (Yogyakarta: Logung Pustaka, 2004), h. 110-111.

33 Lihat KUHP Pasal 1 ayat 1.

34‘Abd al-Qādir ‘Awdah, Al-Tashrī’al-Jinā'̂....,jilid I, h. 121.

182 || Volume 22, Nomor 2, Oktober 2012

Jurnal Pemikiran Hukum Islam 
Unsur kedua adalah materiil, yaitu sifat melawan hukum. Artinya seseorang dikenai delik jarimah atas dasar perilakunya, baik dengan sikap berbuat maupun sikap tidak berbuat. Unsur ini dalam fikih jināyah disebut al-rukn al-maddi. Adapun unsur moril adalah berkenaan dengan pelaku (mukallaf), yaitu orang yang dapat dimintai pertanggungjawaban atas tindak pidana yang dilakukannya. Dalam fikih jināyah, unsur moril ini disebut al-rukn al-adabī. Kriteria riddah di atas, seperti alāqil, al-bāligh dan bi ikhtiyārih adalah termasuk unsur moril.

Sedangkan yang dimaksud dengan unsur khusus adalah unsur-unsur yang bersifat khusus, yaitu unsur yang hanya terdapat pada peristiwa pidana (jarimah) tertentu. Itu berarti setiap tindakan jarīmah tidak sama unsurnya. Adapun kriteria yang menjadikan hukuman riddah dapat dijatuhkan adalah: Pertama, al-'âqil, yaitu berakal. Itu berarti riddah yang dilakukan orang gila adalah tidak sah. Ia tidak berdosa karenanya. Kedua, al-bāligh, yaitu orang yang sudah dewasa. Al-bāligh juga sebutan bagi orang cakap hukum. Ketiga, atas kehendak sendiri (bi ikhtiyārih). Posisi niat menjadi penting sebagai tolok ukurnya. Itulah sebabnya dalam pengertian definitif Wahbah al-Zuhaylī di atas, aspek niat merupakan bagian dari jenis riddah atau al-riddah bi 'l-qalb. Di luar riddah bi 'l-qalb ada juga al-riddah bi 'lqawl, yaitu tindakan riddah dalam bentuk pernyataan verbal.

Selain tiga kriteria di atas, Sayyid Sābiq dalam Fiqh al-Sunnah memberikan kriteria lain yang menyebabkan seseorang menjadi murtad, yaitu: ${ }^{35}$ Pertama, mengingkari persoalan-persoalan agama yang dimaklumi secara aksiomatik, seperti mengingkari keesaan Allah dan alam sebagai ciptaan-Nya. Kedua, memperbolehkan sesuatu yang telah disepakati seluruh kaum Muslimin sebagai perkara haram, seperti menghalalkan arak, zina. Ketiga, mengharamkan segala yang telah disepakati kaum Muslimin sebagai perkara halal, seperti makanan-makanan yang enak. Keempat, mencaci maki atau meremehkan Rasulullah saw. Demikian halnya dengan mencaci Nabi-Nabi Allah yang lain. Kelima, mencaci maki agama, alQur'an dan hadis, tidak melaksanakan ketentuan keduanya dan menganggap undang-undang ciptaan manusia lebih unggul daripada al-Qur'an dan hadis; Keenam, mengaku mendapat wahyu; Ketujuh, membuang mushaf di tempat kotoran, menghina dan menganggap remeh terhadap kandungannya; dan kedelapan, meremehkan nama dari nama-nama Allah, perintah, larangan-Nya,

\footnotetext{
35al-Sayyid Sābiq, Fiqh al-Sunnah, Jilid III, h. 227-228.
} 
kecuali jika ada alasan karena baru masuk Islam atau tidak mengerti hukumnya. Sebab, jika ia mengingkari hal-hal tersebut karena alasan tidak mengerti, ia tidak dianggap kafir.

\section{Sanksi Hukum terhadap Tindak Pidana Riddah (Murtad)}

Sebagaimana disebutkan terdahulu bahwa tindak pidana riddah termasuk kategori jarīmah ḥudūd. Ini berarti bahwa penetapan sanksi dan hukumannya didasarkan kepada naș. Berdasarkan penalaran deduktif ulama, disimpulkan bahwa sanksi atas pidana riddah dikelompokkan ke dalam dua bagian: sanksi utama dan sanksi tambahan. Sanksi utama atas tindak pidana riddah adalah hukuman mati berupa dibunuh (al-qatl), sebgaimana pendapat mayoritas ulama, yang didasarkan pada hadis Nabi: "Barang siapa yang berganti agama (murtad), maka bunuhlah dia". (H. R. Bukhari). ${ }^{36}$ Hadis lain menyebutkan bahwa:

"Dari Mu'adz ibn Jabal Ra. (ia menceritakan) tentang adanya seorang laki-laki yang telah masuk Islam, kemudian dia kembali ke agama Yahudi, (Mu'adz ibn Jabal berkata): aku tidak akan duduk sampai dia (orang murtad tersebut) dihukum bunuh, itulah ketetapan Allah dan Rasul-Nya. Lalu orang tersebut diperintahkan untuk dihukum bunuh". (HR. Bukhari Muslim).37

"Dari Ibn Abbas ra. (ia menceritakan) tentang seorang buta. Ibu kandungnya adalah seorang wanita hamba sahaya yang melakukan penghinaan terhadap Rasulullah Saw. Meskipun telah dilarang, wanita tersebut tidak menghentikan perbuatannya. Dan pada suatu malam, anaknya yang buta itu mengambil semacam benda pegangan lalu diletakkannya pada perut wanita itu, dan sambil bertelekan pada benda itu dia bunuh wanita tersebut. Sementara itu, Rasulullah datang (menyaksikannya) lalu beliau bersabda: Lihatlah, wanita itu halal darahnya". (HR. Abu Dawud). ${ }^{38}$

Hadis pertama bersifat general dan literal. Siapa pun yang melakukan tindakan riddah dikenai sanksi bunuh. Riddah dalam konteks hadis ini adalah seseorang yang pindah agama (al-tabdī $)$. Itu berarti sejak dini sudah memeluk Islam. Ini berbeda dengan konteks literal hadis kedua. Yang murtad adalah orang yang semula Yahudi, lalu masuk Islam, dan kemudian kembali kepada agamanya (alrujū'). Namun sebagian ulama Syafi'iyah berpendapat bahwa seorang yang

\footnotetext{
36Muhammad ibn Ismāîl al-Kaḥlān̄̄ al-Shan'ānī, Subul al-Salām, Juz III (Bandung: Maktabah Dahlan, t. th.), h. 265, hadis ke 6.: Sayyid Sābiq, Fiqh al-Sunnah, Jilid III, h. 229.

37al-Ṣan'ānī, Subul al-Salām, h. 264, hadis no. 5.

38 Ibid., h. 266, hadis no. 7.
}

184 || Volume 22, Nomor 2, Oktober 2012

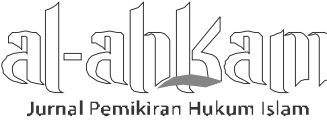


beragama Yahudi yang kemudian memeluk agama Kristen juga digolongkan sebagai pelaku murtad. ${ }^{39}$ Secara definitif pendapat ini tidak sejalan dengan makna denotatif ulama. Bahkan secara legalitas formal tidak berdampak hukum. Karena itu ulama Hanafiyah memberi penegasan bahwa seseorang dikategorikan murtad apabila ia beralih dari agama Islam ke agama lain.40

Adapun hadis ketiga bukan dalam konteks al-tabdìl dan al-rujü', melainkan dalam konteks penghinaan kepada Nabi. Dalam terminologi fikih jināyah, yang disebut terakhir dinamakan jarimmah tashabbabu 'alā dīn al-ghayr. Sedangkan yang disebut pertama dinamakan jarimah al-riddah. Lebih spesifik lagi pelaku jarimah tasyabbabu 'alā dīn al-ghayr adalah seorang wanita. Dan yang menjatuhkan sanksi adalah bukan Nabi, melainkan putra korban sendiri. Hadis ketiga secara definitif menunjukkan bahwa sanki atas pelaku riddah tidak dibedakan antara laki-laki atau wanita, bahkan wanita pun dikenai sanksi yang sama. Kecuali Abu Hanifah yang berpendapat bahwa wanita yang murtad tidak dikenakan hukum bunuh, melainkan wajib dikurung dan disuruh bertobat sampai dia kembali beragama Islam. Alasan Abu Hanifah adalah karena Rasulullah SAW melarang membunuh wanita. ${ }^{41}$ Meskipun demikian, ulama sepakat atas pemberian kesempatan bertobat bagi pelaku murtad sebelum eksekusi dijatuhkan. Bahkan pemberian kesempatan itu merupakan keniscayaan (wajib hukumnya). Demikian pendapat jumhur ulama. ${ }^{42}$ Adapun batasan waktu pemberian kesempatan, sebagian ulama lainnya tidak membatasinya. Hanya saja, demikian Sayyid Sābiq, sampai ada dugaan kuat bahwa pelaku murtad tetap teguh dalam kemurtadannya, maka pada saat itulah hukum bunuh dilaksanakan. ${ }^{4}$

Menurut A. Hasan, hukuman atas pelaku riddah semacam ini (keluar dari Islam lalu memerangi Allah serta Rasul-Nya) ada tiga alternative, yaitu dibunuh, disalib dan atau diasingkan. Menurut A. Hassan, Islam sekali-kali tidak pernah memaksa orang untuk masuk Islam, tetapi juga tidak mengizinkan orang yang beragama

${ }^{39}$ Ibid., h. 265.

40 Ibid.

41al-Sayyid Sābiq, Fiqh al-Sunnah h. 456; lihat pula, al-Ṣan'ānī, Subul al-Salām, h. 265. Lihat Wahbah al-Zuhaylì, al-Fiqh al-Islāmī, h. 187

42Wahbah al-Zuhaili, Ibid., Lihat pula Ibn Rushd, Bidāyat al-Mujtahid wa Nihāyat al-Muqtașid, Juz II (Beirut: Dār al-Fikr, t. th.), h. 343.

43al-Sayyid Sābiq, Fiqh al-Sunnah, h. 458. 
Islam pindah ke agama lain. ${ }^{44}$ Alasan lain, orang yang keluar dari Islam lebih bisa diyakini kalau ia akan membuat propaganda palsu terhadap Islam. Selanjutnya A. Hanafi menjelaskan bahwa sanksi bunuh atas orang murtad disebabkan oleh hilangnya jaminan hak atas keselamatan jiwanya. Ketika ia menjadi Muslim, maka jiwanya dalam jaminan. Karena itu, ketika ia meninggalkan Islam, maka jaminannya pun hilang dengan sendirinya. 45

Selain sanksi utama berupa hukuman mati, pelaku riddah juga dikenai sanksi tambahan, yaitu berupa hilangnya kepemilikan terhadap hartanya (al-mușadarah).46 Menurut Abu Hanifah, Malik dan al-Syafi'i hilangnya kepemilikan terhadap hartanya terhitung sejak pelaku berbuat riddah. Oleh karena itu, begitu ia murtad, hartanya wajib ditahan (yukhjaru 'alayh). Tetapi jika ia kembali masuk Islam, kepemilikan terhadap hartanya dikembalikan lagi seperti semula. Jika ia meninggal dunia atau dihukum bunuh atau bergabung dengan musuh, maka hilanglah kepemilikan terhadap hartanya. Hal itu semata-mata dikarenakan riddah-nya. Karena itu, menjadi hilang pula keterpeliharaan ('iṣmah) terhadap hartanya. ${ }^{47}$ Hilangnya jaminan kepemilikan harta orang murtad di atas menurut ulama Hanabiliah bukan sematamata disebabkan oleh tindakan riddah-nya. Oleh karena itu, hilangnya jaminan keselamatan atas kepemilikan hartanya dihitung sejak pelaku riddah tersebut meninggal dunia atau sejak pelaku dihukum bunuh. Di samping itu, dengan hilangnya jaminan keselamatan jiwanya berarti hilang pula jaminan keselamatan hartanya. ${ }^{48}$

\section{Kritik Makna Murtad dan Implikasi Hukumnya}

Pembahasan ini akan melacak tentang konsep murtad dalam al-Qur'an dan bentuk sanksi atas mereka. Pelacakan diawali dengan merujuk kepada term murtad yang digunakan al-Qur'an. Pengungkapan al-Qur'an tentang terma murtad mengambil dua bentuk, yaitu langsung dan tidak langsung. Pengungkapan langsung, yakni ayat-ayat yang secara redaksional menggunakan terma murtad dan atau yang seakar dengannya berupa derivasi kata murtad itu sendiri. Hasil

\footnotetext{
${ }^{44}$ Alawī 'Abbas al-Māliki \& Hasan Sulayman al-Nūrī, Ibānah al-Aḥkām; Sharh Bulūgh al-Marām (t.tp: Al-Hidayah Publication, 2011), h. 190.

${ }^{45}$ A. Hanafi, Asas-asas Hukum Pidana Islam (Jakarta: Bulan Bintang, 1967), h. 261.

46‘Abd al-Qādir 'Awdah, al-Tashrī’ al-Jināî̄...., Juz I, h. 662.

47Wahbah al-Zuhaylī, al-Fiqh al-Islāmī..., h. 189.

48Ibid., h. 190.
}

186 || Volume 22, Nomor 2, Oktober 2012

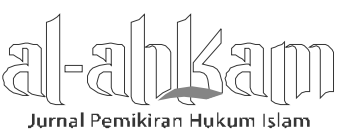


pembacaan deduktif terhadap al-Qur'an menunjukkan bahwa kata murtad tidak ditemukan di dalamnya secara literal (lafžiyyah), melainkan dalam bentuk konotatif (ma'nawiyyah). Makna konotatif mana masih dalam ruang bentuk derivasinya, hanya saja secara konotatif ia bermakna murtad. Secara konotatif, terdapat beberapa ayat yang menunjukkan arti murtad, yaitu: QS. al-Baqarah: 217, QS. Âli 'Imrān: 100, QS. al-Mā'idah: 54, QS. Āli 'Imrān:149, QS. al-Baqarah: 109, QS. Yūnus: 100, dan QS. Muhammad: 25. Ayat-ayat tersebut secara literal tidak menggunakan term murtad.

Kata murtad sendiri secara etimologis berasal dari kata radda-yaruddu-riddan, yang berarti kembali dan berpaling ke belakang. Maksud kembali ke belakang adalah kembali kepada agama sebelumnya. Karena itu kata ridda dalam ayat di

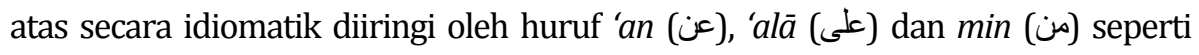
dalam kalimat yaruddu 'an dīnikum (بردوعن دينكم), yaruddūkum 'alā a'qābikum

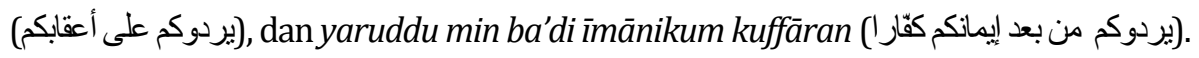
Selain merujuk kepada kata radda-yarudd, juga merujuk kepada kata irtaddayartaddu-irtidādan. Secara morfologi kata murtad merupakan bentuk isim al-fā'il (subjek, pelaku) dari kata irtadda-yartaddu-irtidādan-murtad. Demikian terdapat dalam QS. al-Baqarah: 217; al-Māidah: 54; dan Muhammad: 25. Secara konotatif, bentuk kalimat di atas menunjukkan bahwa murtad adalah mereka yang masuk Islam kemudian kembali kepada agamanya sebelumnya. Dengan kata lain, kata riddah dan atau dirivasinya dalam konteks ayat mengandung makna "meninggalkan Islam untuk kembali kepada kekufuran".

Adapun ungkapan tidak langsung yang dimaknai murtad adalah ayat-ayat yang secara redaksional tidak menggunakan term murtad dan atau derivasinya, tetapi secara subtansial menunjukkan makna murtad, seperti yang ditunjukkan oleh QS. Āli 'Imrān: 86, QS. Âli 'Imrān: 90, QS. Āli 'Imrān: 106, QS. Âli 'Imrān: 177, QS. al-Nisā': 137, QS. al-Naḥl: 106, dan QS. al-Ḥajj:11. Secara literal tidak satu pun ayat tersebut menggunakan term murtad dan atau dirivasinya. Namun secara subtansial, ketujuh ayat itu mengisyaratkannya. Isyarat tersebut mengambil empat

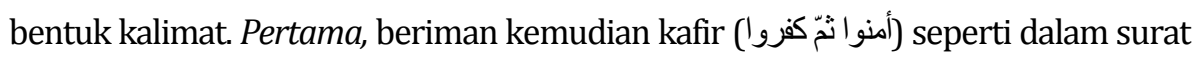
al-Nisā': 137. Kedua, kafir sesudah beriman (كفروا بعد إيمانهم) seperti dalam surat Āli

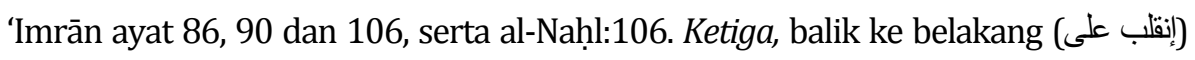
seperti dalam surat al-Hajj ayat 11. Keempat, menukar atau mengganti iman dengan kekafiran (انشتروا الكفر بالإيمان), seperti dalam surat Āli 'Imrān:177.

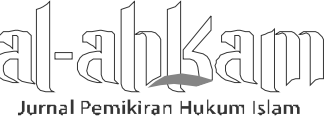

Volume 22, Nomor 2, Oktober 2012 
Adapun sanksi atas murtad dalam ayat-ayat tersebut, tidak satu pun bersifat fisik, melainkan non fisik. Mereka akan memperoleh kerugian di dunia dan di akhirat. ${ }^{49}$ Kerugian di dunia berupa Allah tidak akan mencintainya; ${ }^{50}$ sebaliknya mereka dimurkai; 51 tidak mendapat petunjuk atau hidayah;52 dan seluruh amalnya dianggap sia-sia. ${ }^{53}$ Sedangkan di akhirat kelak wajah mereka menjadi hitam ${ }^{54}$ dan tidak akan mendapat ampunan. ${ }^{55}$ Sebaliknya yang mereka peroleh adalah siksa berat; ${ }^{56}$ mereka dimasukkan ke dalam neraka jahanam. Mereka kekal di dalamnya. ${ }^{57}$

Selain siksa di atas, mereka juga akan mendapatkan laknat dari Allah. Demikian pula para malaikat dan semua manusia melaknatnya. Bahkan ketika menebus dirinya dengan emas seisi bumi untuk memperoleh pengampunan, Allah tidak akan mengampuninya. Kecuali mereka bertobat dan melakukan amal kebajikan. Jika tidak, mereka memperoleh siksa, dan tidak pula mendapatkan penolong. Dengan demikian, dapat dipahami bahwa sanksi atas orang murtad adalah sanksi moral dan ukhrawi; dan bukan sanksi fisik, kecuali jika ia memusuhi Islam, tegas Maḥmūd Shalțūt.58 Pandangan Mạ̣mūd Shalțūt ini didasarkan kepada surat al-Anfāl: 39.

Dengan demikian, hadis Nabi yang menegaskan secara tekstual hukum bunuh atas murtad "man baddala dīnahu faqtulūh" harus dipahami secara kontekstual. Dalam hal ini Ibn Rushd menegaskan bahwa penerapan hadis ini bukan kepada orang yang keluar dari Islam (pindah agama), tetapi kepada mereka yang murtad yang hendak memerangi kaum Muslimin. ${ }^{59}$ Dengan demikian, konteks hadis tersebut adalah perang, dan yang dikenai hukum mati adalah mereka kaum pria yang terlibat sedangkan wanita tidak termasuk di dalamnya.

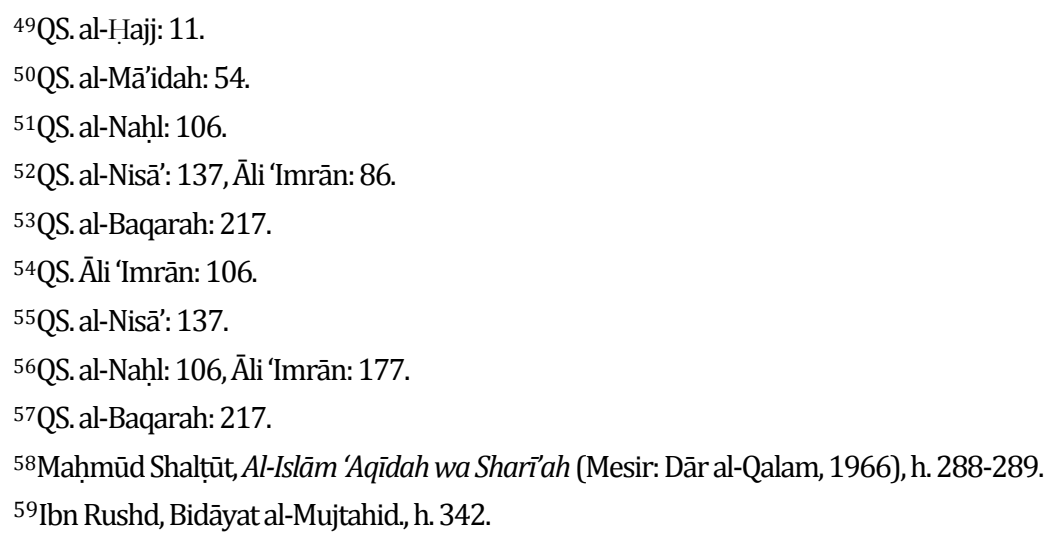


Bahkan orang yang murtad harus diberi kesempatan untuk kembali dan bertobat, serta melaksanakan kebajikan sebagai tebusan atas kekufurannya sebagaimana ditegaskan dalam QS. Āli 'Imrān: 89: "Kecuali orang-orang yang tobat, sesudah (kafir) itu dan mengadakan perbaikan, karena sesungguhnya Allah maha pengampun lagi maha penyayang". Kesempatan tersebut merupakan isyarat bahwa hukuman mati bukan yang dikehendaki oleh syari' (pembuat hukum: Allah SWT). Jika hukuman mati yang dikehendaki, maka tentu tidak perlu adanya tobat. Kesempatan tobat bukan dimaksudkan mendorong orang-orang murtad untuk tetap dalam kemurtadannya, melainkan agar mereka tidak berputus asa dan mau kembali kepada keimanan, sebagai harapan mendapat pengampunan Allah. Seandainya orang-orang murtad harus segera dihukum mati, tentu saja mereka tidak akan memiliki kesempatan untuk berfikir untuk kembali bertobat.

Adapun kritik atas hadis tentang sanksi riddah sebagaimana dua hadis berikut yang artinya:

"Dari Ibn Mas'ud berkata: Rasulullah SAW bersabda: Tidak halal darah orang yang telah bersaksi bahwa tiada Tuhan selain Allah dan bahwasanya aku (Nabi) adalah utusan Allah, kecuali karena tiga perkara: orang yang membunuh jiwa di balas jiwa, orang yang menikah kemudian berzina dan orang yang meninggalkan agamanya serta memisahkan diri dari jama'ah".60

"Muhammad ibn al-Ṣālih menceritakan kepada kami, Sufyan ibn 'Uyaynah mengabarkan kepada kami, dari Ayyub, dari 'Ikrimah, dari Ibn Abbas, ia berkata: Rasulullah SAW bersabda: Barang siapa yang menukarkan agamanya, maka bunuhlah ia".61

Kedua hadis di atas diriwayatkan oleh imam al-Bukhāri. Apa yang diriwayatkan olehnya, dipandang valid mayoritas ulama, kecuali Muhammad al-Ghazāīi, kritikus hadis kontemporer. Salah satu cara pembacaan terhadap hadis adalah mengedepankan prinsip mendahulukan al-Qur'an atas hadis. Kebenaran hadis harus dikonfirmasi dengan ajaran dasar al-Qur'an. Karena itu, Muhammad alGhazālī, termasuk orang yang tidak segan-segan menolak hadis jika matan (isi materi) nya tidak sejalan dengan makna universal al-Qur'an, meskipun hadis tersebut memiliki transmisi-mata rantai (sanad) hadis yang tergolong valid (sahịh).

60al-Bukhārī, Șaḥiḥ al-Bukhārī, Jilid IV (Beirut: Dār al-Fikr, 1401/1981), h. 38; Ibn Mājah, Sunan Ibn Mājah, Juz II (Beirut: Dār al-Kutub al-'Ilmiyyah, t. th.), 847, hadis no. 2533.

61al-Bukhārī, Șaḥị̣ al-Bukhārī, Jilid VIII, h. 50; Ibn Mājah, Sunan Ibn Mājah, h. 848, hadis no. 2535.

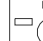

Jurnal Pemikiran Hukum Islam 
Ia menegaskan, rangkaian perawi 'rantai emas' tidak menolong matan yang rapuh. 62

Studi kritis atas hadis murtad bukan untuk menolaknya, melainkan untuk menemukan konteks historis dan meletakkannya dalam pemahaman proporsional. Secara hermeneutik, suatu hadis lahir bukan dalam ruang hampa sejarah. Ada sejumlah faktor pendukung yang melatarbelakanginya. Dengan prinsip ini, hadis-hadis tentang hukuman mati atas pelaku riddah (murtad) dikritisi.

Di dalam hadis pertama disebutkan bahwa orang Muslim boleh dibunuh karena tiga hal. Satu di antaranya —-dalam pemahaman ulama hukum — adalah orang yang murtad. Sementara redaksional hadis tersebut berbunyi: meninggalkan agamanya dan memisahkan (al-tārik) dirinya dari komunitas Islam (aljamā'ah). Dalam versi lain, Șaḥị̣ Muslim, menggunakan frase al-mufāriq li aljamā'ah. ${ }^{63}$ Itu berarti pemisahan diri dari komunitas merupakan persyaratan yang sangat penting dalam kasus riddah. Sedangkan secara kontekstual, frase ini mengandung pengertian bahwa orang-orang Muslim yang memisahkan diri atau meninggalkan orang-orang Muslim lain untuk kemudian bergabung dengan pasukan musuh menunjukkan bahwa situasi pada saat itu adalah situasi perang. Mereka yang murtad dibunuh adalah bukan karena menukar agamanya. Akan tetapi lebih disebabkan oleh permusuhannya. Pemahaman seperti ini secara deduktif sejalan dengan apa yang dijelaskan dalam surat al-Māidah: 33 dan alNisā': 89. Namun jika yang murtad tersebut lari dan berlindung ke dalam sejumlah suku yang tidak melakukan peperangan terhadap orang-orang Islam, maka ia tidak boleh di bunuh, sebagaimana dijelaskan dalam lanjutan ayat surat al-Nisā': 90.

Atas dasar itu, Syekh Maḥmūd Shalțūt menegaskan bahwa permasalahan tindak pidana murtad (riddah) ini perlu ditinjau kembali. Alasannya adalah karena kebanyakan ulama berpandangan bahwa sanksi hudūd tidak bisa dilakukan atas dasar hadis aḥ̄d. Sementara kekufuran itu sendiri bukanlah penyebab halalnya darah seorang pelaku murtad. Akan tetapi yang menyebabkan halalnya darah pelaku murtad adalah sikap permusuhan dan perlawanannya (al-muḥārabah wa al-'udwān)

\footnotetext{
${ }^{62}$ Muhammad al-Ghazālī, al-Sunnah al-Nabawiyyah bayn Ahlu l-Hadīth wa I-Fuqahā', diterjemahkan oleh Muhammad al-Baqir dengan judul Studi Kritis Atas Hadis Nabi saw.: Antara Pendekatan Tekstual dan Kontekstual (Bandung: Mizan, 1991), h. 191.

63al-Nawāwī, Șahīh Muslim bi Sharḥ al-Nawāwī, JilidXI (Beirut: Dār al-Fikr, 1403/1983), h. 164. 
terhadap kaum Muslimin.64 Sementara makna fundamental al-Qur'an justru melarang pemaksaan terhadap agama, ${ }^{65}$ dan bahkan ditegaskan kembali dalam QS. Yūnus: 99.

\section{Rekonstruksi Hukuman Riddah Serta Implikasi Yuridis dan Metodologis}

Pembahasan tentang perspektif al-Qur'an dan studi kritis atas hadis tentang riddah di atas menegaskan bahwa hukuman bunuh yang ditegaskan al-Qur'an bukan karena kemurtadan, melainkan kejahatan pidana dan permusuhannya kepada Allah dan rasul-Nya. Pemaknaan terhadap hadis pun harus diletakkan dalam konteks ini. Terlebih riwayat-riwayat di atas justru menunjukkan secara faktual bahwa Nabi saw. tidak pernah melakukan hukuman mati atas mereka yang murtad. Imam al-Syafi'i pernah mengatakan: "Sebagian manusia pernah memeluk Islam kemudian kembali murtad, tetapi masih menampakkan keimanannya secara zhahir, namun Rasulullah tidak membunuhnya".66 Bahkan ketika menemukan wanita terbunuh, beliau berkata: "Mengapa wanita ini dibunuh?" Ibn 'Abbās sendiri pernah berkata: "Wanita murtad hanya dipenjara, tidak dibunuh." Karena memang Rasulullah melarangnya, meskipun dalam situasi perang. 67

Selain merasa perlu melakukan tinjauan ulang terhadap pandangan mayoritas tentang hukuman pembunuhan bagi riddah, Mahmud Syaltut dalam karyanya AlIslām; 'Aqīdah wa Sharī'ah, secara fundamental mengingatkan bahwa al-Qur'an dengan tegas melarang adanya pemaksaan agama sebagaimana termaktub dalam QS. al-Baqarah: 256 dan QS. Yūnus: 99.68 Pendapat yang sama juga dikemukakan oleh M. Hasbi Ash-Shiddiqy bahwa sanksi bunuh kepada setiap orang yang murtad adalah berlawanan dengan firman Tuhan yang terdapat dalam surat al-Baqarah: 256 diatas. ${ }^{69}$

\footnotetext{
${ }^{64}$ Maḥmūd Shalțūt, al-Islām Aqīdah wa Sharīah, h. 289.

${ }^{65}$ QS. al-Baqarah: 156.

66Ṭaha Jabir al-Ilwani, Là Ikraha fi 'I-Dīn, terj. Aa Fuad Muhlis (Jakarta: Srigunting, 2005), h. 147.

${ }^{67}$ Muhammad Munir Adhhabī, Qatl al-Murtadd: al-Jarīmah allatī Harramaha T-Islām, terj. A. Hakiem Sarazy dan Azka Hammam Syaerozie (Jakarta: Nigos, Menjelajah Alam Gagas, 2002), h. 139.

${ }^{68}$ Maḥmūd Shalțūt, al-Islām 'Aqīdah wa Sharī'ah (Mesir: Dār al-Qalam, 1966), h. 289.

${ }^{69}$ M. Hasbi Ash-Shiddiqy, Pedoman Hukum Syar'i yang Berkembang dalam Islam Sunny, Jilid II (Jakarta: Penerbit Pustaka Islam, 1952), h. 245.
} 
Tanpa mengurangi kerja keras intelektual (ijtihād) mayoritas ulama atas pembacaan mereka secara deduktif terhadap nas al-Qur'an dan hadis sehingga sampai kepada konsensus bersama tentang hukuman mati atas murtad, hasil tinjauan kritis atas al-Qur'an, hadis dan sejarah, menemukan bahwa pandangan tersebut tidak memiliki basis epistemologi. Bahkan telaah atas al-Qur'an menunjukkan bahwa tidak satu pun teks secara șārih-lafziyyah yang mengarah kepada penyimpulan mayoritas ulama tersebut. Sebaliknya, al-Qur'an menegaskan sanksinya bersifat eskatalogis; dan menegasikan sanksi fisik.

Pandangan al-Qur'an ini diperkuat oleh praktek Nabi bahwa secara non verbal (baca: hadis fi'li) Nabi SAW tidak pernah menjatuhkan hukuman mati atas pelaku riddah, kecuali mereka melakukan serangkaian tindakan pidana lainnya. Hal sama dipraktekkan Abu Bakar al-Siddīq di masa kepemimpinannya. Kenyataan historis yang didemonstrasikan oleh Nabi baik ketika Fathu Makkah, yakni murtadnya sebagian besar orang-orang Makkah saat menyikapi Isra-Mi'raj, keluarnya dari Islam sebagaian orang yang pernah ikut hijrah ke Habashah dan menuliskan wahyu, serta bukti otentik dari perjanjian Hudaybiyyah yang ditandatangani Nabi, sungguh suatu hal yang tak terbantahkan. Bahkan fakta-fakta itu, menggugurkan apa yang diijma'kan mayoritas ulama dan sekaligus mendekonstruksi apa yang dirumuskan dalam fikih jināyah.

Dengan ungkapan lain, memasukkan tindakan riddah sebagai jarīmah ḥudūd adalah tidak sesuai dengan fakta-fakta normatif dan historis (tekstual dan kontekstual). Karena itu rumusan tentang jenis jarīmah ḥudūd tidak lagi tujuh macam, melainkan enam macam, karena murtad tidak lagi masuk dalam kategori dan jenis jarīmah ḥudūd. Keenam jenis jarīmah ḥudūd dimaksud adalah zina, qadhf (menuduh zina), pencurian, perampokan atau penyamunan (hirābah), pemborontakan (al-baghy), dan minum-minuman keras.

Pemahaman terhadap konsep riddah dan implikasi hukumnya diatas, dapat diketahui bahwa terdapat implikasi metodologis yakni bahwa pendekatan historisitas ayat atau asbāb al-nuzūl sebagai penggambaran atas latar belakang turunnya sebuah ayat, menjadi bagian penting dalam memahami ayat. Sedangkan pendekatan yang bertumpu kepada analisis linguistik, menjadi hal penting bagi pendekatan tekstual. Dalam terminologi ușūl al-fiqh, yang pertama berpegang kepada kaidah: al-ibratu bi 'umūm al-lafụi lā bi khuṣūṣ al-sabāb. Sementara yang

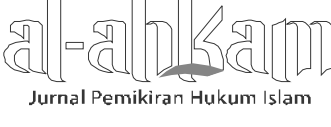


kedua berpegang kepada kaidah: al-ibratu bi khușūṣ al-sabāb lā bi 'umūm al-lafẓi. ${ }^{70}$ Disamping itu penggunaan takwil dalam memaknai riddah dan hukumannya penting dilakukan dalam memberi makna sebuah teks karena sesungguhnya baik al-Qur'an maupun hadis, keduanya adalah teks terbaca. Sedangkan pembacaan atas keduanya meniscayakan pendekatan terkait.

\section{Kesimpulan}

Berdasarkan uraian di atas dapat disimpulkan bahwa mayoritas ulama yang berpendapat bahwa murtad termasuk tindakan pidana sebagaimana pendapat ulama mayoritas yang mendasarkan pada QS. al-Baqarah: 217 dan hadis Nabi: "Barangsiapa yang menukar agamanya, maka bunuhlah ia," memiliki sejumlah kelemahan. Tinjauan al-Qur'an menunjukkan bahwa sanksi atas murtad adalah sanksi ukhrawi; dan bukan sanksi fisik. Sanksi tersebut berupa tidak mendapatkan petunjuk, tidak mendapat ampunan, dan amal dinilai sia-sia. Mereka juga mendapat laknat dari Allah dan para malaikat, sehingga di akhirat mereka dimasukkan kedalam neraka. Tetapi jika bertobat dan mengikutinya dengan amal kebaikan, maka Allah memberi pengampunan.

Upaya rekonstruksi makna sangat penting dilakukan karena secara historis bahwa Nabi tidak pernah membunuh orang yang murtad. Kebijakan ini dilanjutkan oleh Abu Bakr dan Umar. Abu Bakar tidak pernah memerangi ahli riddah (hurub al-riddah) hanya karena alasan kemurtadannya, melainkan mereka karena keengganannya membayar zakat yang diikuti dengan serangkaian pembunuhan terhadap kaum Muslimin, serta upaya mereka melepaskan diri dari pemerintahan Abu Bakar disertai pemberontakan-pemberontakan. Umar ibn Khatțāb pun demikian. Dengan demikian hukuman mati bagi pelaku riddah harus dikaji ulang karena berdasarkan kajian filosofis dan historis bahwa pembunuhan bagi pelaku riddah lebih karena alasan politis.[a]

\section{DAFTAR PUSTAKA}

'Abduh, Muhammad, Tafsīr al-Manār, Juz II, Beirut: Dār al-Ma'ārif li 'l-Ṭibā'ah wa 'Nashr, t.th.

\footnotetext{
h. 22 .

${ }^{70}$ Nasruddin Umar, Argumen Kesetaraan Jender Perspektif al-Quran (Jakarta: Paramadina, 2001),
}

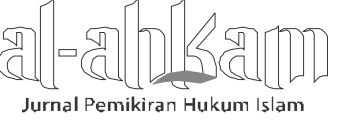


Abdur Rahman ibn Smith

'Alawī 'Abbas al-Māliki \& Ḥasan Sulayman al-Nūrī, Ibānah al-Aḥkām; Sharḥ Bulūgh al-Marām (t.tp: Al-Hidayah Publication, 2011.

A. Hanafi, Asas-asas Hukum Pidana Islam, Jakarta: Bulan Bintang, 1967.

A. Jazuli, Fiqh Jinayah Upaya Menanggulangi Kejahatan dalam Islam, Cet. 1, Jakarta: Raja Grafindo Persada, 1996.

Adhhabī, Muhammad Munir, Qatl al-Murtadd: Al-Jarīmah allatī Harramaha I-Islām, terj. A. Hakiem Sarazy dan Azka Hammam Syaerozie, Jakarta: Nigos, Menjelajah Alam Gagas, 2002.

al-Anșāri, Ibn Manẓūr, Lisān al-'Arab, Vol II, Mesir: al-Dār al-Mișriyyāt li 'l-Ta'līf wa al-Nashr, t.th.

Ali, Abdullah Yusuf, The Glorious Kur'an, Translation and Commentary, Beirut: Dār al-Fikr, t. th.

Ash-Shiddiqy, M. Hasbi, Pedoman Hukum Syar'i Yang Berkembang Dalam Islam Sunny, Jilid II, Jakarta: Penerbit Pustaka Islam, 1952.

'Awdah, 'Abd al-Qādir, al-Tashrī' al-Jinā'ī al-Islāmī, Muqāranan bi al-Qānūn al-Waḍ'ī, Jilid I, Beirut: Dār al-Kitāb al-Bābī, t. th.

al-Bukhārī, Muḥammad ibn Ismāîl, Șaḥịh al-Bukhārī, Beirut: Dār al-Fikr, 1401 $\mathrm{H} / 1981$.

al-Bukhārī, Muhammad ibn Ismāîl, Matn al-Bukhārī bi Hāshiyyah al-Sindī, Jilid IV, Beirut: Dār al-Fikr, 1995.

Effendi, Djohan, "Harus Ada Kebebasan Tidak Beragama", dalam Wajah Liberal Islam di Indonesia, [Editor], Luthfi Asy-Syaukani, Jakarta: Jaringan Islam Liberal, 2002.

al-Farmawy, Abdul Hayy, Metode Tafsir Maudhu'i, Terj. Suryan A. Jamrah, Jakarta: Rajawali Press, 1994.

al-Ghazālī, Muhammad, Al-Sunnah al-Nabawiyyah Bayn Ahlu 7-Hadīth wa I-Fuqahā, diterjemahkan oleh Muhammad al-Baqir dengan judul Studi Kritis Atas Hadis Nabi saw.: Antara Pendekatan Tekstual dan Kontekstual, Bandung: Mizan, 1991.

al-Hamashī, Muhammad Ḥasan, Qur'an Karim: Tafsīr wa Bayān, Damaskus: Dār alRushd, t.th.

Humaydi, Fahmi, Demokrasi Oposisi dan Masyarakat Madani, terj. Muhammad Abdul Goffar E.M., Bandung: Mizan, 1996.

Ibn Rushd, Bidāyat al-Mujtahid wa Nihāyat al-Muqtașid, Juz II, Beirut: Dār al-Fikr, t. th. Ibn Mājah, Sunan Ibn Mãjah, Juz II, Beirut: Dār al-Kutub al-'Ilmiyyah, t.th.

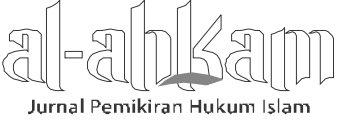


al-Ilwani, Thaha Jabir, Lā Ikraha fi 'l-Dīn, terj. Aa Fuad Muhlis, Jakarta: Srigunting, 2005.

al-Jābirī, Muḥammad 'Abed, Naḥnu wa 'l-Turāth: Qirā'at Mu'așirah fi Turathinā alFalsafi, Beirut: al-Markaz al-Thaqafi al-'Arabī, t.th.

Madjid, Nurcholis, Islam Kemodernan dan Keindonesiaan, Bandung: Mizan, 1989.

Muhadjir, Noeng, Metodologi Penelitian Kualitatif, Yogyakarta: Rake Sarasin, 1996.

Munajat, Makhrus, Dekonstruksi Hukum Pidana Islam, Yogyakarta: Logung Pustaka, 2004.

Munawwir, Ahmad Warson, Kamus Al-Munawwir, Yogyakarta: Yayasan Pondok Pesantren Krapyak, 1995.

al-Munawwar, Said Aqil Husin, Fikih Hubungan Antar Agama, Jakarta: Ciputat Press, 2005.

al-Nawāwī, Imām, Ṣahīḥ Muslim bi Sharḥ al-Nawāwī, Jilid XI, Beirut: Dār al-Fikr, 1403/1983.

Noerwahidah AH, Pidana Mati dalam Hukum Pidana Islam, Surabaya: al-Ikhlas, 1994.

Riḍā, Muhammad Rashīd, Tafsīr al-Manār, Jilid III, Beirut: Dār al-Fikr, t. th.

Sābiq, Al-Sayyid, Fiqh al-Sunnah, Jilid II, Beirut: Dār al-Fikr, 1983.

Shalțūt, Maḥmūd, al-Islām 'Aqīdah wa Sharī’ah, Mesir: Dār al-Qalam, 1966.

Shihab, M. Quraish, Wawasan al-Qur'an, Bandung: Mizan, 1996.

al-Ṣan'ānī, Muhammad ibn Ismā'îl al-Kahlānī, Subul al-Salām, Juz III, Bandung: Maktabah Dahlan, t. th.

al-Syāthi', 'Aisyah Abdurrahman bintu, Manusia: Sensitivitas Hermeneutik al-Qur'an, terj. M. Adib al-Arief, Yogyakarta: LKPSM, 1997.

Umar, Nasruddin, Argumen Kesetaraan Jender Perspektif al-Qur'an, Jakarta: Paramadina, 2001.

al-Zuhaylī, Wahbah, al-Fiqh al-Islāmiy wa Adillatuh, Juz VII, Damaskus: Dār al-Fikr al-Mu'āṣir, t.th.

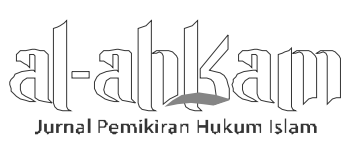

Volume 22, Nomor 2, Oktober 2012 
196 || Volume 22, Nomor 2, Oktober 2012 